\title{
BIBLIOTECAS
}

\section{REVISTAS DE HISTÓRIA EXISTENTES EM ALGUMAS BIBLIOTECAS DE SAO PAULO}

A propósito da publicação de relação de revistas de história existentes em nossas bibliotecas (Revista de História n. ${ }^{\circ} 11$, pg. 201212 ), recebemos de d. Odúlia Xavier Leite a carta que abaixo transcrevemos.

BIA-210.

São Paulo, 13 de Novembro de 1952.

Exmo. Sr. Prof. Dr. Eurípedes Simões de Paula.

D. D. Diretor da "Revista de História"

Ceppital.

\section{Prezado Senhor}

Tenho o prazer de escrever-Ihe a fim de transmitir-lhe a lista anexa, referente a 25 títulos de revistas de história existentes nesta Biblioteca e que, entretanto, não constam da relação por V. Excia. publicada na "Revista de História", n.o 11 , de 1952.

Cumpre-me dizer-lhe ainda que a coleção da "Revista do Instituto Histórico e Geográfico Brasileiro", aqui existente, inicia-se em 1839 e não 1939 como foi publicado.

Supondo possam as presentes informações serem úteis a V. Excia., apressome em apresentar-lhe meus atenciosos cumprimentos.

ODULIA XAVIER LEITE

Chefe da' Biblioteca.

Biblioteca do Instituto de Administração.

Rua Dr. Vila Nova, 268, $4 .^{\circ}$ andar. Capital. 
1. - Anais do Museu Paulista. São Paulo, Museu Paulista, 1922.

2. - Anais do $10^{\circ}$ Congresso de História Nacional, 1914. Rio de Janeiro, Imprensa Nacional, $5 \mathrm{v}$.

3. - Anais do $20^{\circ}$ Congresso de História Nacional, 1931. Rio de Janeiro, Imprensa Nacional, $5 v$.

4. - Anais do $3 .^{\circ}$ Congresso de Histótia Nacional, 1938. Rio de Janeiro, Imprensa Nacional, 10v.

5. - Anais do $4 .^{\circ}$ Congresso de História Nacional, 1949. Rio de Janeiro, Imprensa Nacional, 1951, v. 10 e 11 :

6. - Atiais do Congresso Internacional de História da América, 1922. Rio de Janeiro, Imprensa Nacional, 9v.

7. - Anuário Genealógico Brasileiro. São Paulo, Instituto de Estudos Genealógicos, 1939-1944.

8. - Atas da :Câmara da Cidade de São Paulo. São Pauloł. Departamento de Cultura, n. ${ }^{\circ}$ s 4, 6-10, 12, 16-71.

9. - Biblioteca Genealógica Brasileira. São Paulo, Instituto Genealógico Brasileiro, 6v .

10. - Boletim da Academia Portuguêsa de História. Lisboa, Academia Portuguêsa de História, 1937.

11. - Boletim do Departamento do Arquivo do Estado de São Paulo. São Paulo, Departamento do Arquivo. 1942-1948.

12. - Documentos interessantes para a história e costumes de São Paulo. São Paulo, Departamento do Arquivo, n. ${ }^{\circ}$ 1-57 e 62-72.

13. - Genealogia Paulistana. São Paulo, 1-9.

14. - Indices genealógicos brasileiros. São Paulo, Instituto Genealógico Brasileiro, n. ${ }^{\circ}$ s. 1-4.

15. - Instituto Pan-Americano de Geografia e História. Assembléia inaugural. 1932-33. Rio de Janeiro, Imprensa Nacional, $4 \mathrm{v}$.

16. - Inventários e testamentos. São Paulo, Departamento do Arquivo, 1-33.

17. - Journal de la Societé des Américanistes. Paris, .Societé des Américanistes, 1896.

18. - Paulistânia: documentário. São Paulo, 1940-44.

19. - Registro geral da Câmara da Cidade de São Paulo. São Páulo, Departamento de Cultura, 1-38.

20. - Revista de História. São Paulo, 1950. 
21. - Revista do Arquivo Municipal. São Paulo, Departamento de Cultura, 1943, n. ${ }^{\circ} 1$ - Indice Anual.

22. - Revista do Instituto de Estudos Genealógicos. São Paulo, Instituto de Estudos Genealógicos, 1937-1939.

23. - Revista do Museu Paulista. São Paulo, Museu Paulista, 1895-1947, 1947.

24. - Revista do Serviço do Patrimônio Histórico e Artístico Nacional. Rio de Janeiro, M. E., 1937-1944.

25. - Revista Genealógica Brasileira. São Paulo, Instituto Genealógico, 1940-44.

E. SIMÕES DE PAULA 